\title{
Mineral katkılı betonların kimyasal durabilitesinin toplam bağlayıcı miktarı ve eşdeğer su/çimento parametreleriyle beraber incelenmesi
}

\author{
Anıl Niş** \\ İstanbul Gelişim Üniversitesi, Mühendislik-Mimarlık Fakültesi, İnşaat Mühendisliği Bölümü, İstanbul \\ Geliș Tarihi (Recived Date): 24.10.2018 \\ Kabul Tarihi (Accepted Date): 22.03.2019
}

\section{Özet}

Bu çalışmada değişik mineral katkılar içeren farklı betonların hava, \%3,5 deniz suyu ve $\% 5$ sülfürik asit ortamlarında durabilite performansı toplam bağlayıcı miktarı ve eşdeğer su/çimento oranı parametreleri ile beraber incelenmesi amaçlanmıştır. Deney kapsamında farklı kimyasal etkilere karşı kontrol betonu (K), uçucu kül katkılı beton $(U)$, cüruf katkılı beton (C), ve hem uçucu kül hem de silis dumanı katkılı beton (US) üretilmiştir. Kontrol $(K)$ ve uçucu kül betonlarının $(U)$ eşdeğer su/çimento oranı 0.45 olup, bağlayıcı miktarları sırasılla 400 ve 470 kg/m3'tür. Cüruflu $(C)$ ve hem uçucu kül hem de silis dumanı içeren betonların (US) betonların eşdeğer su/çimento oranı 0.53 olup, bağlayıcı miktarları 500 ve $440 \mathrm{~kg} / \mathrm{m3}$ 'tür. Eşdeğer su/çimento hesapları TS 13515 standardına göre belirlenmiştir. Üretilen betonların farklı ortamlardaki durabilite performansı görsel inceleme, ağırlı ve basınç dayanımlarındaki değisşimler ile belirlenip, toplam bağlayıcı ve eşdeğer su/çimento oranı parametrelerinin beton performansina etkileri kapsamlı bir şekilde irdelenmiştir. Sonuçlara göre, uçucu küllü ve silis dumanlı beton diğer betonlardan daha yüksek eşdeğer su/çimento oranına ve diğerlerinden daha az bă̆layıcı miktarı içermesine rağmen kimyasal etkilere karşı en iyi performansı göstermiştir. En kötü kimyasal performansı ise yüksek CaO içerdiğinden cüruflu ve kontrol betonlar göstermiştir. TS 13515 standardında kullanılan çimento eşdeğerlik katsayısı uçucu kül için uygun sonuçlar verirken, cüruflu ve silis dumanı içeren betonların eşdeğer su/çimento hesaplamalarında kullanılmak üzere TS 13515 standardına önemli tavsiyelerde bulunulmuştur.

Anahtar kelimeler: Silis dumanı, ис̧иси kül, cüruf, deniz suyu, sülfürik asit.

\footnotetext{
*Anıl Niş, anis@gelisim.edu.tr, http://orcid.org/0000-0001-9092-8088
} 


\title{
Investigation of chemical durability of mineral additive concretes with total binder amounts and equivalent water/cement ratio parameters together
}

\begin{abstract}
In the study, different mineral additive concretes were investigated under air, 3,5\% seawater and 5\% sulfuric acid environments considering the parameters of total binder amounts and equivalent water/cement ratio together. For this purpose, control concrete $(K)$, and concretes including fly ash $(U)$, slag $(C)$, fly ash and silica fume (US) were produced. The equivalent water/cement ratio for control concrete and concrete with fly ash was 0,45 and binder amounts were 400 and $470 \mathrm{~kg} / \mathrm{m} 3$, respectively. The equivalent water/cement ratio for concrete with slag, concrete with fly ash and silica fume was 0,53 and binder amounts were 500 and $440 \mathrm{~kg} / \mathrm{m} 3$, respectively. The equivalent water/cement ratio was calculated using TS13515 standard. Chemical resistance was determined via visual inspection, change in weight and compressive strength. According to the results, concrete with fly ash and silica fume showed superior chemical resistance while it had higher equivalent water/cement ratio and lower binder materials. The concrete with slag and control concrete showed the lowest performance due to the higher $\mathrm{CaO}$ content. The equivalence coefficient defined by TS13515 standard for fly ash showed good results with experiments; however, significant recommendations have been made to the standard for the calculations of equivalent water/cement ratio of concretes with slag and silica fume.
\end{abstract}

Keywords: Silica fume, fly ash, slag, seawater, sulfuric acid.

\section{Giriș}

Günümüzde betonda aranan en önemli özelliklerinden birisi de kimyasal etkilere karşı durabilitedir. Günümüzde betonda bağlayıcı malzeme olarak en fazla Portland çimentosu kullanılmaktadır. Portland çimento üretimi dünyadaki $\mathrm{CO} 2$ salınımının yaklaşık \%8'ini bulmaktadır [1] ve ayrıca üretimi sırasında çok fazla enerji gerektirdiğinden hem ekonomik değildir hem de iklim değişikliğine yol açmaktadır. Global ekonomide çelik fiyatlarının yükselmesi betonu kaçınılmaz yapı malzemesi yapmıştır ve nüfusun artmasıyla zamanla artacak çimento ihtiyacı yaşadığımız çevreyi daha da çok kirletecektir. Çevresel ve ekonomik zararlı etkileri en aza indirgemek/önlemek için betonda çimentoya yakın özellikler gösteren, termik santral ve demir çelik fabrikaların atık ürünleri olan yüksek fırın cürufu, uçucu kül ve silis dumanı gibi mineral katkılar betonda dayanım ve durabiliteyi artırmak amacıyla kullanılmaktadır [2].

Uçucu kül katkılı beton ile yapılan çalışmalarda çimento yerine \%30'dan fazla kullanılan uçucu kül katkısının betonun uzun süreli dayanım performansını önemli derecede azaltmıştır [3]. Yapılan diğer bir çalışma da [4] uçucu kül oranı \%15, \%25, $\% 33, \% 42, \% 50$ ve $\% 58$ oranlarında çimento yerine kullanılıp numunelerin basınç dayanımı incelenmiş ve betona katılabilecek en uygun uçucu kül miktarının yaklaşık \%40'a kadar olduğunu, daha fazla uçucu kül kullanımı durumunda betonun basınç dayanımında azalmalar meydana gelmiştir. ACI 211 [5] standardı ise yüksek dayanımlı 
betonlarda uçucu külün çimento yerine $\% 15$ ile $\% 25$ ' i arasında kullanılması tavsiye edilmektedir. Uçucu külün \%30-\%40 oranlarında kullanımı betonun basınç dayanımı 180.güne kadar arttırdığ 1 belirtilmiş ve aynı betonun klorür difüzyonu \%100 çimento içeren betona göre önemli miktarda azalmıştır [6]. Uçucu külün puzolanik özelliğinden dolayı çimentonun genelde \%30'u oranında kullanılması durumunda betonun geçirimliliğini azalttığı belirtilmiştir [7]. Başka bir çalışmada ise uçucu küllü betonlarda porozitenin erken yaşlarda arttığını fakat ortalama gözenek çapının azalmasından dolayı (uçucu külün çimentodan ince olması) uçucu küllü betonların geçirimliliğinin daha az olduğu belirtilmiştir [8].

Yüksek fırın cürufu kullanımı ise betonun sülfat etkisine karşı durabilitesini olumlu yönde etkilediği ve sülfata karşı yüksek durabilite için yüksek fırın cürufunun çimentonun en az \%50'si kadar kullanılması gerektiği önerilmiştir ve ayrıca cüruftaki alümina miktarının \%11'in altında olması tavsiye edilmiştir [9]. Yapılan bir çalışmada cüruf katkısı çimento ağırlığının \%0, \%30, \%50, \%65 ve \%80 oranlarında kullanılmış ve cüruf miktarının çimento ağırlığının $\% 50$ oranında kullanımına kadar basınç dayanımı kaybının az olduğunu fakat $\% 50$ oranından fazla cüruf kullanımında ise beton basınç dayanımlarında ciddi düşüşler meydana geldiği belirtilmiştir [10]. Aynı çalışmada ayrıca betonların donma-çözülme performansları incelenmiş ve cüruf miktarının \%50'den yüksek olması durumunda donma-çözülme direncinin düştüğünü ve \%80 oranında cüruf içeren karışımların en düşük donma-çözülme direncine sahip olduğu belirtilmiştir [10]. Klor geçirgenliği incelenen bir çalışmada ise $\% 25, \% 50$ ve $\% 75$ oranlarında cüruf içeren karışımlar kullanılmış ve \%50 cüruf içeren betonun klor geçirgenliği en az çıkmıştır ve \%50 oranının beton dayanımı da azaltmadığı için en uygun cüruf oranı olduğu belirtilmiştir [11]. Yapılan diğer bir çalışmada cüruflu betonların dayanım gelişmesi incelenmiş ve cürufun \%50'den fazla kullanılması halinde cüruf etkinliğinin (aktivitesinin) düştüğü belirtilmiştir [12].

Silis dumanı içeren betonla yapılan bir çalışmada $\% 6$ ve $\% 12$ silis dumanı içeren betonların klor içeren ortamlarda elektriksel dirençlerinde artma gözlemlenmiş ve silis dumanının kimyasal ortamlarda kullanılabileceğini tavsiye etmişlerdir [13]. Bir çalışmada, kullanılan çimentonun ve agregaların tipine, silis dumanı miktarına ve kür koşullarına bağlı olarak silis dumanının betonun basınç dayanımını \%30 oranlarında arttırdığını ve basınç dayanımının artışından dolayı betonun çekme ve eğilme dayanımını arttırdığı belirtmişlerdir. Ayrıca silis dumanı kullanımı betonda geçirgenliği, 1sıl genleşmeyi, büzülme ve sünmeyi azalttığı, kimyasal saldırılara ve korozyon direncini ise iyileştirdiği belirtilmiştir $[14,15]$. Başka bir çalışmada ise silis dumanının çimento miktarının 5\%'ine kadar kullanılması durumunda betonun erken dayanımı arttırdığı, fakat 180 günlük basınç dayanımları incelendiğinde silis dumanı ilavesinin betonların ileriki yaşlardaki basınç dayanımını azalttığını ifade etmişlerdir [16]. Basınç dayanımındaki azalmanın nedenleri arasında, silis dumanı topaklanarak bağlayıcıda zayıflık yaratması [17-19], ve silis dumanının \%4 ile \%5'lik miktarın bağlayıcı olarak hidratasyona uğraması ve $\% 5$ 'ten daha yüksek miktarının ise hidratasyona girmemesi [20] olarak gösterilebilir. Yapılan bir çalışmada \%2, \%4, \%6, \%8 ve \%10 oranlarında silis dumanı kullanımı incelenmiş, $\% 8$ oranında silis dumanı kullanımının betonun $\mathrm{pH}$ değerini düşürmediği ve \%8'den daha fazla silis dumanı kullanımının klor bağlama kapasitesini etkilemediği belirtilmiştir [21]. Başka bir çalışmada ise $\% 8$ oranından daha az silis dumanı içeren betonlarda geçirimliliğin düşmediği bu yüzden durabilite için betonda en az \%8 oranında silis dumanı kullanılması gerektiği belirtilmiştir [22]. 
$\mathrm{Bu}$ çalışmada kimyasal etkilere karşı beton durabilitesinin incelemesi amaciyla literatürde bağlayıcı malzeme (çimento + mineral katkı) olarak kullanılabilecek en uygun oranlar uçucu kül için \%25-\%30, yüksek fırın cürufu için $\% 50$ ve silis dumanı için ise $\% 8$ olarak belirlenmiștir. Bu oranlar kullanılarak farklı tipte betonlar üretilmiş ve bu betonların değişik kimyasal ortamlardaki durabilite performansı incelenmiştir.

\section{Deneysel çalışmalar}

\subsection{Malzemeler ve malzeme karışım oranları}

Betonlar; kontrol betonu (bağlayıcı olarak çimento), uçucu kül içeren beton (bağlayıcı olarak \%75 çimento + \%25 uçucu kül), yüksek fırın cüruflu beton (bağlayıcı olarak $\% 50$ çimento $+\% 50$ cüruf), ve uçucu kül ve silis dumanı içeren beton (bağlayıcı olarak $\% 62$ çimento + \%30 uçucu kül + \%8 silis dumanı) olacak şekilde üretilmiştir. Çimento olarak CEM I 42.5 R tipi çimento, uçucu kül olarak ise düşük kireç içerikli F-tipi uçucu kül kullanılmıştır. Uçucu kül Çatalağzı termik santralinden, cüruf İskenderun demir çelik fabrikasından ve silis dumanı ise BASF firmasından (MasterRoc MS610) temin edilmiştir. Kullanılan malzemelerin özellikleri Tablo 1'de verilmiştir.

Tablo 1. Çimento, uçucu kül, cüruf ve silis dumanının kimyasal ve fiziksel özellikleri

\begin{tabular}{ccccc}
\hline Kompozisyon & Çimento & Uçucu Kül & Cüruf & Silis dumanı \\
\hline $\mathrm{CaO}(\%)$ & 64.28 & 2.10 & 37.25 & 0.03 \\
$\mathrm{SiO}_{2}(\%)$ & 4.91 & 54.76 & 38.37 & 90.21 \\
$\mathrm{Al}_{2} \mathrm{O}_{3}(\%)$ & 20.17 & 25.26 & 11.89 & - \\
$\mathrm{Fe}_{2} \mathrm{O}_{3}(\%)$ & 3.41 & 6.28 & 1.05 & - \\
$\mathrm{MgO}(\%)$ & 1.18 & 2.08 & 8.13 & - \\
$\mathrm{SO}_{3}(\%)$ & 2.84 & 0.2 & 0.38 & 0.35 \\
$\mathrm{Na}_{2} \mathrm{O}(\%)$ & 0.13 & 0.38 & 0.28 & 0.45 \\
$\mathrm{~K}_{2} \mathrm{O}(\%)$ & 0.96 & 4.04 & 1.28 & 0.85 \\
$\mathrm{~K}_{\text {ızdırma Kaybı (\%) }}$ & 1.61 & 3.3 & 0 & 2.87 \\
Özgül Ağırlık $\left(\mathrm{g} / \mathrm{cm}^{3}\right)$ & 3.14 & 2.13 & 2.93 & 2.26 \\
Özgül Yüzey $\left(\mathrm{cm}^{2} / \mathrm{g}\right)$ & 3910 & 3870 & 4320 & 257000 \\
Dayanım Aktivite İndeksi (\%) (gün) & - & $83(28)-97(90)$ & $85(28)$ & $148(28)$ \\
\hline
\end{tabular}

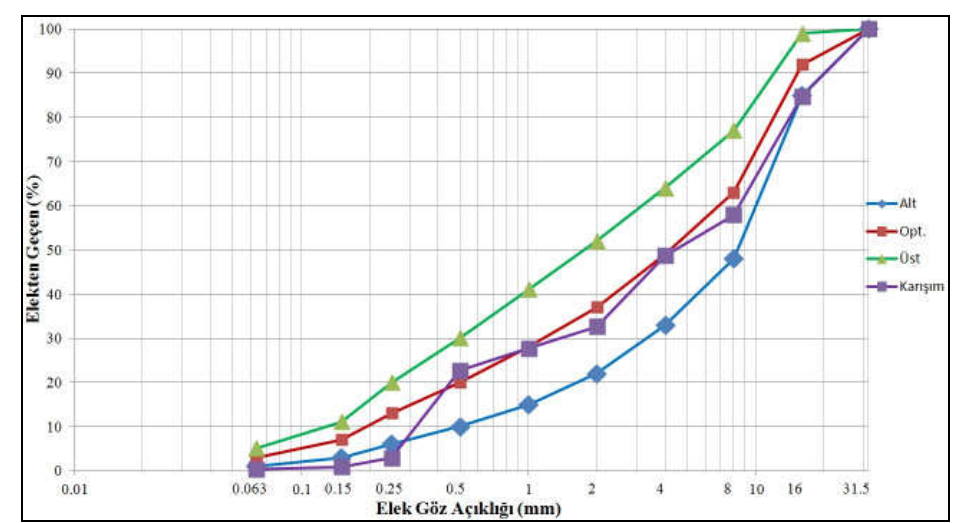

Şekil 1. Betonlarda kullanılan agregaların elek analizi.

Kullanılan agregaların elek analizi Şekil 1'de verilmiştir. Kontrol betonu K, uçucu kül içeren beton $\mathrm{U}$, yüksek fırın cürufu içeren beton $\mathrm{C}$, ve hem uçucu kül hem de silis 
dumanı içeren beton US ile gösterilip kullanılan malzeme miktarları Tablo 2'de verilmiştir. Kimyasal katkı olarak naftalin sülfonat esaslı süperakışlanlaştırıcı kullanılmıştır. S4 kıvamlı beton elde etmek için gerekli süperakışlanlaştırıcı miktarları belirlenmiş ve betonların durabilite performanslarının süperakıșlanlaștırıcı miktarından etkilenmemesi için bütün betonlarda aynı miktarda süperakışlanlaştırıcı kullanılmıştır.

Tablo 2. Betonda kullanılan malzeme miktarları $\left(\mathrm{kg} / \mathrm{m}^{3}\right)$

\begin{tabular}{|c|c|c|c|c|}
\hline \multirow{2}{*}{ Bileşenler } & \multicolumn{4}{|c|}{ Miktar $\left(\mathrm{kg} / \mathrm{m}^{3}\right)$} \\
\cline { 2 - 5 } & $\mathrm{K}$ & $\mathrm{U}$ & $\mathrm{C}$ & $\mathrm{US}$ \\
\hline $\mathrm{Su}$ & 180 & 180 & 180 & 180 \\
\hline Çimento & 400 & 353 & 250 & 275 \\
\hline Uçucu Kül & - & 117 & - & 130 \\
\hline Yüksek Fırın Cürufu & - & - & 250 & - \\
\hline Silis Dumanı & - & - & - & 35 \\
\hline Kireçtaşı (5-22 mm) & 1043 & 989 & 974 & 994 \\
\hline Kum (0-4 mm) & 789 & 748 & 733 & 752 \\
\hline Süperakışlanlaştırıcı & 5 & 5 & 5 & 5 \\
\hline
\end{tabular}

Kontrol betonundaki çimento (Ç) miktarı, su/çimento oranı 0,45 olacak şekilde 400 kg/m3 olarak seçilmiştir. Bu miktar TS 13515 standardındaki Çizelge F.2.2' de belirtilen çok zararlı kimyasal ortam için kullanılması gereken minimum çimento miktarının (360 $\mathrm{kg} / \mathrm{m} 3$ ) üzerindedir. Mineral katkı içeren betonlarda ise, uçucu kül betonu için bağlayıcı miktarının ağırlıkça \%25 oranında uçucu kül ikame edilmiş ve toplam $470 \mathrm{~kg} / \mathrm{m} 3$ (353 $\mathrm{kg} \mathrm{Ç}+117 \mathrm{~kg} \mathrm{U}$ ) bağlayıcı malzeme kullanılmıştır. Cüruflu betonda ise cüruf çimento miktarı kadar ikame edilmiş ve toplam $500 \mathrm{~kg} / \mathrm{m} 3(250 \mathrm{~kg} \mathrm{Ç}+250 \mathrm{~kg} \mathrm{C})$ bağlayıcı kullanılmıştır. Uçucu kül ve silis dumanlı beton için toplam bağlayıcı miktarının \%30'u uçucu kül ve \%8'i silis dumanı kullanılmış olup, toplam $440 \mathrm{~kg} / \mathrm{m} 3(275 \mathrm{~kg}$ Ç + $130 \mathrm{~kg}$ $\mathrm{U}+35 \mathrm{~kg} \mathrm{~S}$ ) bağlayıcı malzeme kullanılmıştır. TS 13515 standardına göre mineral katkılar için k katsayısı (çimento eşdeğerlik sayısı) belirtilmekte ve bu değer kullanılan mineral katkının cinsine göre değişmektedir [23]. Standarda göre uçucu kül için k katsayısı 0,4 alınmakta, hesaplamalara katılan uçucu külün miktarı çimento miktarının kütlece \%33'ünü geçemeyeceği belirtilmiştir. Uçucu küllü betonda kullandığımız uçucu kül miktarı çimentonun \%33'ü olduğundan uçucu küllü beton için eşdeğer su/çimento $(180 /(353+353 * 0.33 * 0.4)$ oranı 0,45 'tir. Cüruflu beton için ise $\mathrm{k}$ katsayısı 0,8 alınmaktadır fakat kullanılan cürufun ancak \%45'i eşdeğer su/çimento oranı hesaplarına katıldığ1 için eşdeğer su/çimento oranı cüruflu beton için 0,53 olmaktadır $(180 /(250+250 * 0.45 * 0,8)$. TS 13515 standardına göre uçucu kül ve silis dumanı içeren betonlarda, silis dumanı $\mathrm{k}$ katsayısı 1 alınmakta fakat eşdeğer su/çimento oranı hesaplanırken uçucu kül ve silis dumanı miktarının sırasıyla çimentonun en fazla \%33'ü ve \%11'ini hesaplara katılabilmektedir. Dolayısıyla uçucu kül ve silis dumanı içeren betonlarda da eşdeğer su/çimento oranı 0,53 olmaktadır $(180 /(275+275 * 0,33 * 0.4+275 * 0,11 * 1)$. Bu çalışmada farklı beton tipleri için hem toplam bağlayıcı miktarı hem de standart tarafından belirlenen eşdeğer su/çimento oranı etkisinin havada, deniz suyunda ve asit ortamında incelenmesi amaçlanmıştır.

\subsection{Numunelerin hazırlanmast ve kimyasal solüsyonlarda bekletilmesi}

Karışım prosedürü olarak ilk önce kuru karışımlar (agregalar ve bağlayıcı malzemeler) 2 dakika mikserde karıştııılmıştır. Daha sonra su miktarının tamamı ile süperakışlanlaştırıcının yarısı karıştırılarak miksere 1 dakika içinde dökülüp 1 dakika daha homojen olarak karıştırılmıştır. En son süperakışlanlaştırıcının kalan kısmı 
miksere ilave edilerek karışım 2 dakika daha karıştırılmıştır. Beton karışım süreci 6 dakika olarak ayarlanmıştır. Beton küp numuneleri 150x150x150 mm boyutlarında dökülüp, gerekli sıkıştırma işlemlerinin ardından 24 saat sonra kalıplardan çıkarılmış ve 28. güne kadar kür tankında su içinde kürlenmiştir.

Dökülen beton küp numuneler 28 . gün sonunda $\% 3,5$ deniz suyu $(\mathrm{NaCl})$ ve $\% 5$ sülfürik asit solüsyonlarına konulmuş ve ayrıca betonların kimyasal ortamlardaki performanslarının incelenmesi amaciyla bazı numuneler laboratuvar (hava) ortaminda bekletilmiştir. Kimyasal ve hava ortamlarında bulunan numuneler 60 . ve 90. günlerde maruz bırakıldıkları ortamlardan çıkarılmıştır ve yapılacak testler öncesi asit ve deniz suyuna maruz numunelerin kuruması beklenilmiştir.

\subsection{Kimyasal etkilere maruz kalan numune testleri}

Farklı kimyasal ortamlarda bırakılan numunelerin ağırlık değişimi, görsel inceleme ve basınç dayanımlarındaki değișim 150x150x150 mm küp numuneler kullanılarak incelenmiş olup, kontrol ve mineral katkılı betonların farklı ortamlardaki performansları incelenmiştir. Küp numuneler üzerindeki basınç testi ASTM C39 [24] standardı kullanılarak belirlenmiştir.

\section{Bulgular ve tartışma}

\subsection{Görsel inceleme}

Mineral katkısız kontrol, uçucu küllü, cüruflu ve hem uçucu kül hem de silis dumanlı betonların hava ortamında, \%3,5 deniz suyu ortamında ve $\% 5$ sülfürik asit ortamında 90. gün sonundaki (60 gün farklı ortamlara maruz bırakılmış) betonların yüzeyinde meydana gelen değişimler Şekil 2'de gösterilmiştir. Deniz suyu ortamına maruz bırakılan numuneler görsel olarak incelendiğinde numunelerin dış yüzeylerinde çatlak, dökülme gibi önemli bir değişme olmadığı görülmektedir. Bununla beraber çok belirgin bir renk değişimi olmadığı ve numunelerin diş yüzeylerinde çok hafif yumuşama meydana geldiği için beton numunelerin görsel olarak deniz suyundan fazla etkilenmediği görülmektedir. Literatürde yapılan benzer çalışmalar da deniz suyunun beton numunelerinin dış yüzeylerinde çok belirgin bir etkisinin olmadığını ortaya koymuştur $[25,26]$.

Sülfürik asit $\left(\mathrm{H}_{2} \mathrm{SO}_{4}\right)$ etkisine maruz numunelerin yüzeyleri incelendiğinde kontrol betonu, uçucu kül ve cüruflu betonların diş yüzeylerinde etrenjit ve alçıtaşı oluşumlarının etkisiyle ciddi bir yumuşama olduğu gözlemlenmiş ve numunelerin diş yüzeylerinde dökülme meydana gelmiştir. Uçucu kül ve silis dumanı içeren betonların dış yüzeylerinde de beyaz lekelenmeler gözlemlenmiş olup, dış yüzeyin yumuşama etkisiyle dökülmesi (yüzey erozyonu) fazla olmamıştır. Silis dumanı katkılı numuneler diğer beton numunelerine göre görsel olarak daha iyi durabilite performans1 göstermiştir. Diğer betonlarda daha fazla bozulma olmasının sebebi söz konusu betonların yüksek miktarda $\mathrm{CaO}$ içermesinden kaynaklanmaktadır. Çünkü sülfürik asitte $\left(\mathrm{H}_{2} \mathrm{SO}_{4}\right)$ bulunan sülfatlar $\left(\mathrm{SO}_{4}\right)$ ile betonda bulunan $\mathrm{C}_{3} \mathrm{~A}$ ve $\mathrm{CaOH}$ ile reaksiyona girerek alçıtaşı $\left(\mathrm{CaSO}_{4}\right)$ ve etrenjit $\left(\mathrm{C}_{4} \mathrm{~A}_{3} \mathrm{~S}\right)$ oluştururlar ve eğer betonda $\mathrm{CaO}$ fazla olursa özellikle oluşan alçıtaşı miktarı da fazla olur. Oluşan bu ürünler betonun çatlamasına, yüzeyinin dökülmesine ve dayanımının düşmesine sebep olur [27]. Silis dumanlı ve uçucu küllü betonda ise daha az bozulma olmasının nedeni en düşük $\mathrm{CaO}$ miktarına sahip olması ve silis dumanının inceliği sayesinde betondaki boşlukları doldurması, agrega-çimento ara yüzünü (ITZ) güçlendirmesi ve betondaki geçirimliliğin azalması olarak yorumlanabilir. Bir çalışmada ise mineral katkı kullanımı ile betondaki 
geçirimliliğinin azalma sebebi olarak hem mineral katkıların kılcal boșlukları tıkaması hem de puzolanik reaksiyonlar sonunda kalsiyum hidroksitin kullanılarak daha çok kalsiyum silikat hidrat jeli oluşarak gözeneklerin dolması gösterilmiştir [9]. Daha önce yapılan çalıșmada kimyasal etkilerin (asit, deniz suyu vb.) betonu en diș yüzeyden bozmaya başladığını ve bozulmanın zamanla en dış yüzeyden iç bölgelere doğru arttığını fakat sülfürik asit etkisinin yüzeyden en fazla $20 \mathrm{~mm}$ içeriye girerek betonu etkilediğini belirmişlerdir [28, 29]. Bu çalışmada da basınç deneyleri sonrası kırılmış numuneler incelendiğinde en diş 1-2 cm'lik bir kısmın kimyasal ortamdan etkilendiği iç kısımların bozulmamış olarak kaldığı gözlemlenmiştir.

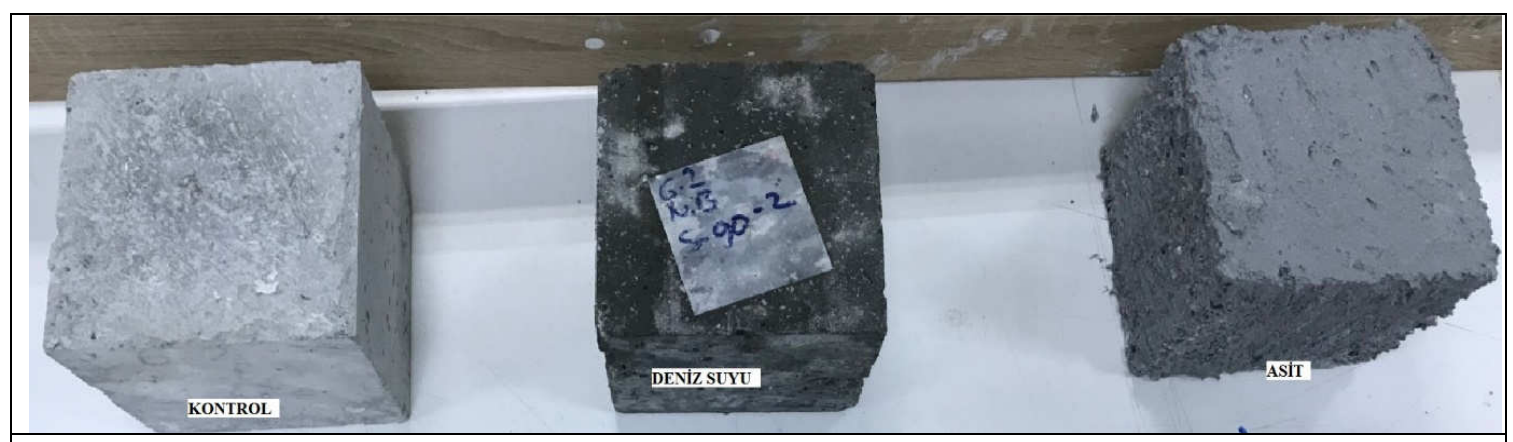

a) 60 gün farklı ortamlarda bekletilen mineral katkı içermeyen betonların (\%100 Ç) görüntüsü

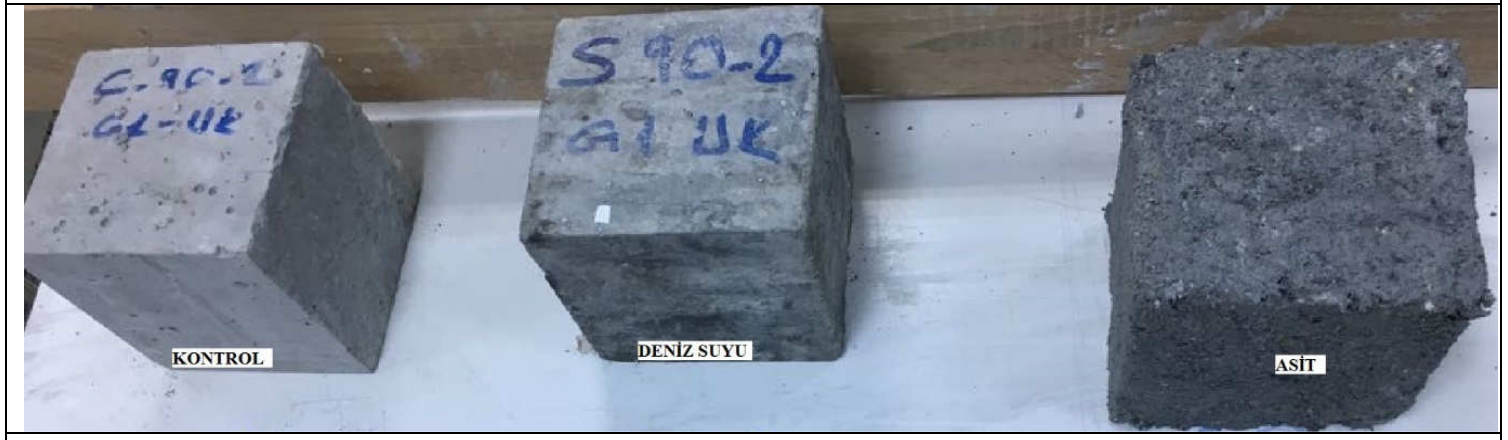

b) 60 gün farklı ortamlarda bekletilen uçucu kül içeren betonların (\%75 Ç + \%25 U) görüntüsü

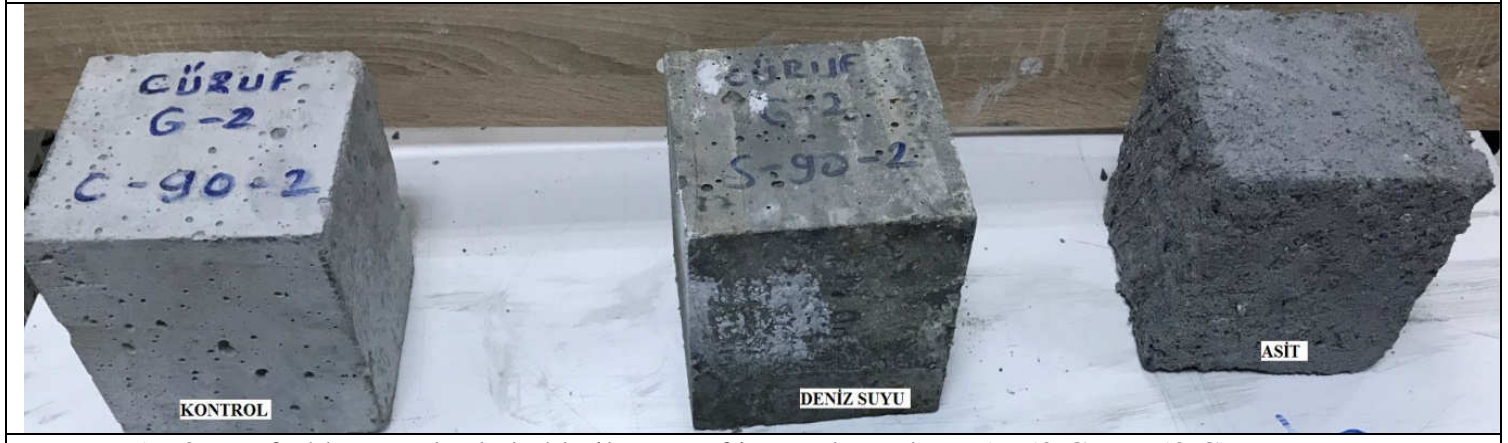

c) 60 gün farklı ortamlarda bekletilen cüruf içeren betonların $(\% 50 \mathrm{Ç}+\% 50 \mathrm{C})$ görüntüsü

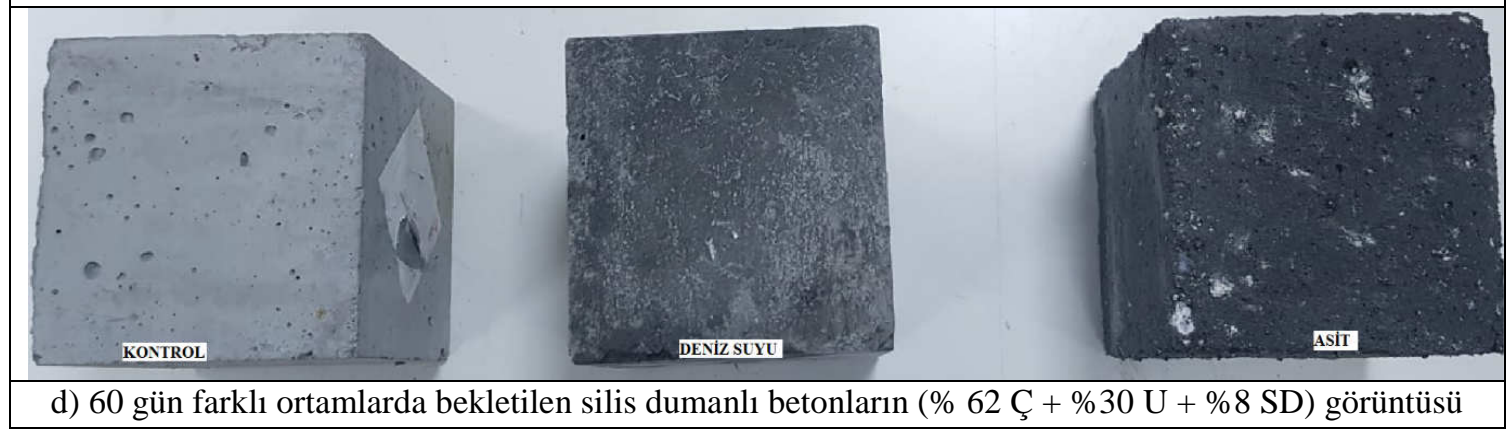

Şekil 2. Farklı kimyasal ortamlar etkisindeki numunelerin görsel olarak incelenmesi. 


\subsection{A Ăırlık değissimi}

Hava ortamına $(\mathrm{H})$, deniz suyu ortamına (D) ve asit (A) ortamına maruz birakılan numunelerin ağırlıkları sırasıyla 30 . gün, 60 . gün ve 90 . günde ölçülmüss ve numunelerin ağırlık değişimi Şekil 3'de gösterilmiştir. Şekil 2'de farklı betonların 30. gündeki ağırlıkları referans alınmış ve numunelerde zamanla meydana gelen ağırlık değişiminin 30.güne göre değişimi \% cinsinden hesaplanmıştır. Ağırlık değişimi sonuçlarına göre, hava ortamında bekletilen numunelerde beton içindeki suyun hidratasyon sırasında buharlaşmasından dolayı numune ağırlıklarında azalma meydana gelmiştir, (Şekil 3.a). Hava ortamında bekletilen numunelerde ağırlık kaybı literatürde de bulunmaktadır [30, 31]. 90. gün ağırlıklarına göre en fazla ağırlık kaybı \%1,92 ile silis dumanı ve uçucu kül içeren numunelerde meydana gelirken, en az ağırlık kaybı ise \%0,5 ile kontrol numunelerinde meydana gelmiştir. Cüruf içeren betonlar ve uçucu kül içeren betonlar yaklaşık olarak aynı ă̆ırlık kaybı ( \%1.7) göstermişlerdir. Ağırlık kaybı devam eden hidratasyon reaksiyonlarını gösterdiğinden, hidratasyon reaksiyonları en fazla olan numuneler silis dumanı ve uçucu kül içeren numunelerdir.

Zhutovsky ve Hooton (2017) yaptıkları bir çalışmada beton numunelerindeki sülfat etkisi incelenmiş ve betondaki bozulmayı en iyi yansıtan parametrenin ağırlık değişimi olduğunu belirtmişlerdir [32]. Bu çalıșma kapsamında da farklı beton numunelerdeki bozulmayı incelemek amacıyla numune ağırlıkları ölçülmüștür. \% 3,5 deniz suyu ortamında bekletilen numunelerin ağıllıklarında zamanla meydana gelen değişim Şekil 2.b.'de gösterilmiştir. Kimyasal ortam dolayısıyla numune ağırlıklarında meydana gelen azalma ve artma miktarlarının çok olması betondaki bozulmanın da fazla olduğunu gösterir. Deniz suyuna maruz bırakılan numunelerin 90.gündeki ağırlıkları incelendiğinde en fazla ağırlık değişiminin kontrol betonunda ve cüruf katkılı betonda olduğu görülmektedir ( \%2). Uçucu kül katkılı numunelerdeki ağıllık değişimi yaklaşık olarak \%1 iken, en az ağırlık değişimi $(\% 0,74)$ silis dumanı ve uçucu kül katkılı betonlarda görülmüştür. Sülfürik asit $\left(\mathrm{H}_{2} \mathrm{SO}_{4}\right)$ etkisindeki numunelerde ise en fazla ağırlık değişiminin kontrol betonunda ve cüruf katkılı betonda olduğu görülmektedir ( $3 \%)$. Uçucu küllü betonlarda \%1,25 ağırlık kaybı meydana gelirken, uçucu kül ve silis dumanlı betonlarda ise $\% 1$ civarında ağırlıkta artma meydana gelmiştir. Sülfürik asit etkisindeki betonlar deniz suyu ortamına göre daha fazla ağırlı değişimi gösterdiğinden sülfürik asit ortamı deniz suyundan daha tehlikelidir. Her iki ortamda da silis dumanı ve uçucu kül içeren (US) betonlar diğer betonlardan daha az etkilenmiştir.

Ağırlık değişiminden bulunan sonuçlar görsel inceleme ile karşılaştırıldığında uçucu kül ve silis dumanı içeren betonların dış görünüşü diğer numunelerden daha iyidir. Kimyasal etkilere maruz kalan betonların ağırlıklardaki değişim diğer çalışmalarda da mevcuttur. [33, 34]. Bazı betonlarda 60. günde ağırlık artması (bir ay kimyasala maruz) meydana gelirken aynı betonun ağırlı̆ıında 90. günde (iki ay kimyasallara maruz) azalma gerçekleşmiştir. Bunun sebebi, sülfürik asit ve deniz suyunda bulunan sülfatlar $\left(\mathrm{SO}_{4}\right)$ difüzyonla beton içine nüfuz ederek çimentodaki $\mathrm{C}_{3} \mathrm{~A}$ ve $\mathrm{CaOH}$ ile reaksiyona girerek alçıtaşı $\left(\mathrm{CaSO}_{4}\right)$ ve etrenjit $\left(\mathrm{C}_{4} \mathrm{~A}_{3} \mathrm{~S}\right)$ oluşumuna neden olurlar [35]. $\mathrm{Bu}$ reaksiyonlar betonda hacim artışına neden olurlar ve beton numunenin ağırlı̆ğ artar. Fakat daha fazla zaman ve kimyasal konsantrasyonlarda bu hacim artı̧ı betonun çatlamasına, dış yüzeyin yumuşayarak beton dış yüzeyinin dökülüp beton ağıllığının azalmasına neden olabilir [36]. Mevcut kimyasal ortam eğer düşük konsantrasyon $(<1000 \mathrm{ppm})$ ise bu durumda betonda ana ürün olarak etrenjit oluşurken, çok yüksek kimyasal ortam konsantrasyonunda $(>8000 \mathrm{ppm})$ betonda ana ürün olarak alçıtaşı oluşmaktadır. Orta kimyasal ortam konsantrasyonlarında ise (1000-8000 ppm) her iki ana ürün oluşumu (etrenjit ve alçıtaşı) mümkündür [37]. 


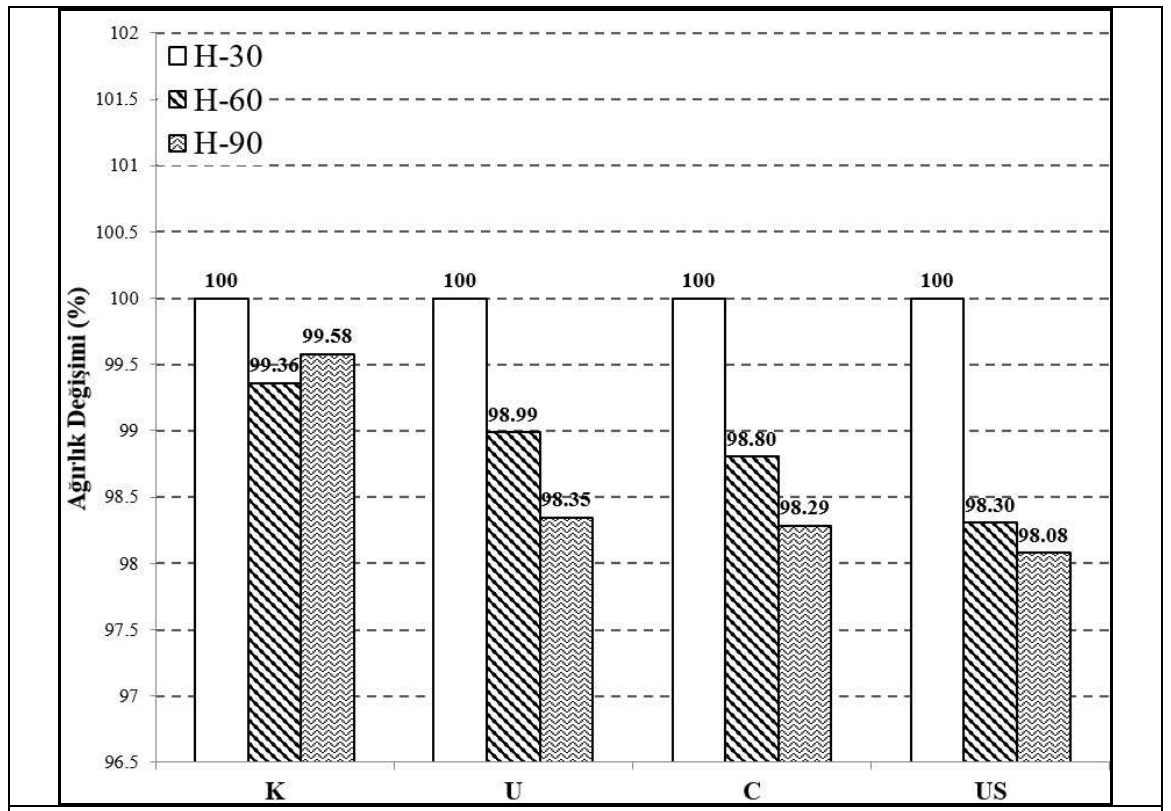

a) Hava ortamında bekletilen numunelerin ağırlık değişimi

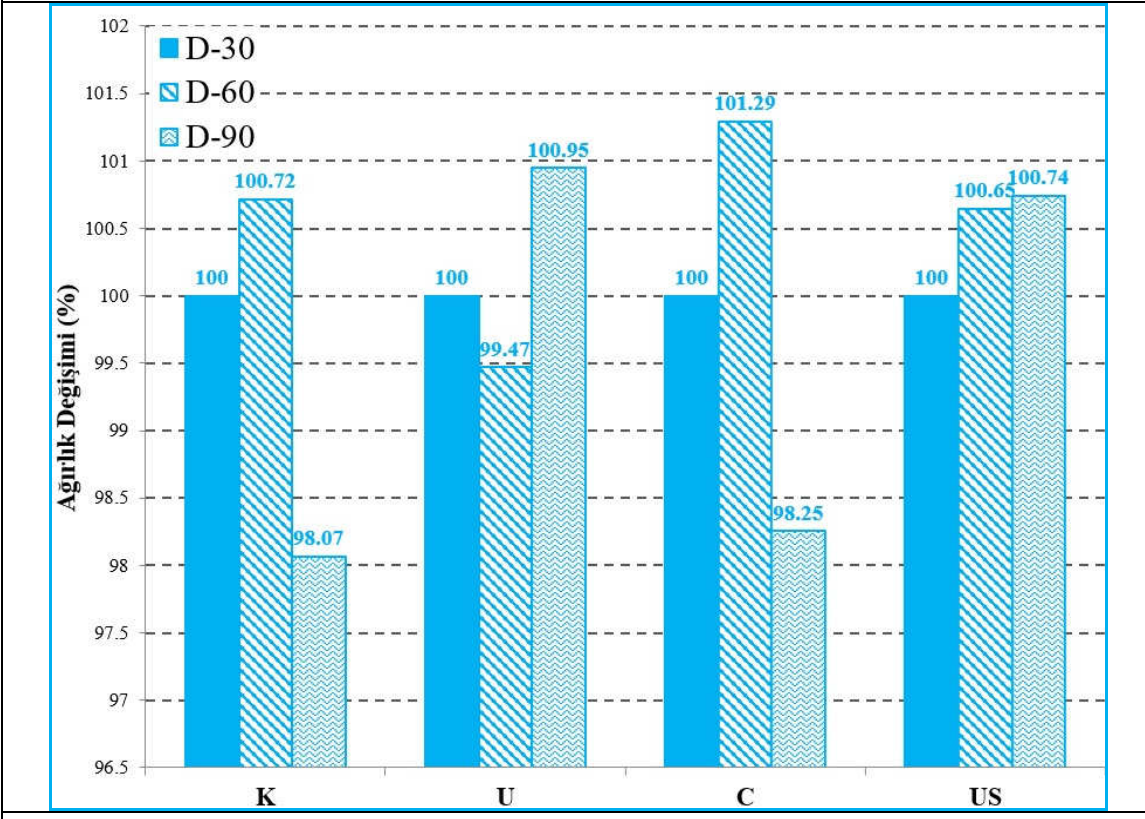

b) Deniz suyu ortamında bekletilen numunelerin ağırlık değişimi

Şekil 3. Farklı kimyasal ortamlar etkisindeki numunelerin ağırlık değişimi. 
NişA.

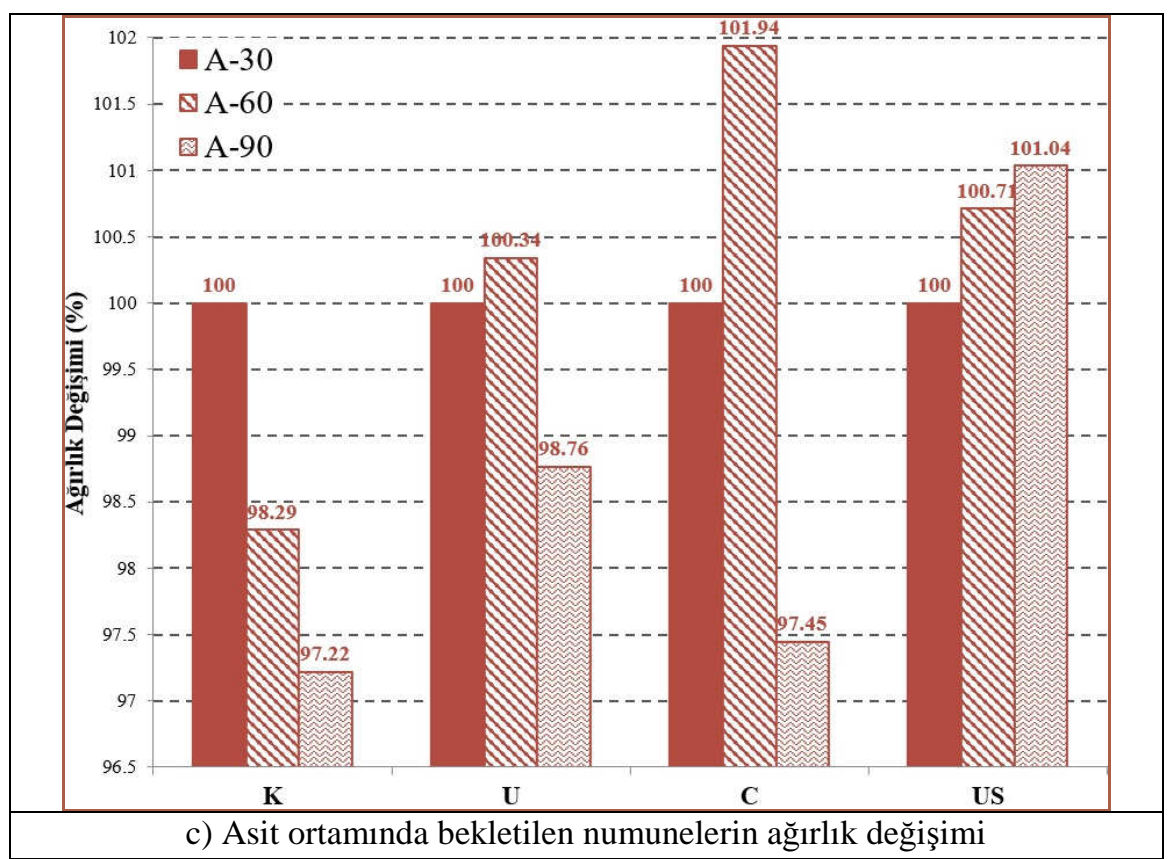

Şekil 3. (Devam1).

\subsection{Basınç dayanımı değişimi}

Beton numunelerinin hava, \%3,5 deniz suyu ve \%5 sülfürik asit ortamlarındaki küp basınç dayanım sonuçları 30.gün, 60. gün ve 90.gün için Şekil 4'de verilmiştir. Hava ortamında bırakılan numunelerdeki basınç dayanım sonuçlarına göre (Şekil 4.a) 90.günde en yüksek dayanım kontrol (\%100 Ç (400kg)) numunelerinde ve uçucu kül içeren $(\% 75 \mathrm{Ç}(353 \mathrm{~kg})+\% 25 \mathrm{U}(117 \mathrm{~kg}))$ numunelerinde $\sim 52 \mathrm{MPa}$ olarak elde edilmiştir. Her iki betonun eşdeğer su/çimento oranı 0,45 'tir ve uçucu kül miktarının tamamı eşdeğer su/çimento hesaplarına girmektedir. Uçucu küllü ve kontrol betonlarının dayanımının benzer olması TS13515 standardına göre uçucu kül için k katsayısının doğru tahmin edildiğinin işaretidir. Cüruflu betonda (\%50 Ç (250 kg) + $\% 50 \mathrm{C}(250 \mathrm{~kg})$ ) eşdeğer su/çimento oranı 0,53 'tür ve 90 . gündeki basınç dayanımı $~ 48$ MPa olarak elde edilmiştir. Burada eşdeğer su/çimento hesaplarına cürufun sadece \%45'i (112,5 kg) girmekte ve kalan 137,5 kg kadar miktar hesaplara katılmamaktadır. Fakat cüruflu betonun basınç dayanımının ( 48 MPa), kontrol ve uçucu küllü betonlarla birbirine yakın olması, cüruf miktarının \%45'ten daha fazlasının eşdeğer su/çimento hesaplarına katılabileceğini ve yaklaşık olarak çimentonun \%55'ine kadar cüruf miktarının eşdeğer su/çimento oranında kullanılabileceği tahmin edilmektedir. Silis dumanı ve uçucu kül içeren betonda $(\% 62$ Ç $(275 \mathrm{~kg})+\% 30 \mathrm{U}(130 \mathrm{~kg})+\% 8 \mathrm{~S}(35$ $\mathrm{kg}$ )) eşdeğer su/çimento oranı 0,53'tür ve 90.gündeki basınç dayanımı $\sim 35 \mathrm{MPa}$ olarak elde edilmiştir. Eşdeğer su/çimento hesaplamasına ise $90,75 \mathrm{~kg}$ uçucu kül $\left(275^{*} 0,33\right)$ ve $30,25 \mathrm{~kg}$ silis dumanı $\left(275^{*} 0,11\right)$ katılmakta $39,25 \mathrm{~kg}$ uçucu kül ve $4,75 \mathrm{~kg}$ silis dumanı eşdeğer su/çimento hesaplarına katılmamaktadır. Eşdeğer su/çimento oranı cüruflu betonla benzer olmasına $(0,53)$ ve kullanılan toplam bağlayıcı miktarının $(440 \mathrm{~kg})$ uçucu küllü beton bağlayıcı miktarına ( $470 \mathrm{~kg}$ ) çok yakın olmasına rağmen silis dumanı içeren betonun basınç dayanımı düşük çıkmıştır. Bunun nedeni olarak daha az çimento kullanımı (düşük $\mathrm{CaO}$ miktarı), eş değer su/çimento hesaplamalarında kullanılan silis dumanı miktarının (çimentonun \%11'i) hepsinin dayanımına katkıda bulunmadığı [20] veya silis dumanının topaklanarak dayanımı olumsuz etkilediği [17-19] belirtilebilir. 
İki ay deniz suyuna maruz bırakılan numunelerin basınç dayanımı sonuçlarına göre, kontrol ve cüruf içeren betonların 90 günlük basınç dayanımında 28 günlük basınç dayanımına göre $\% 2$ ve $\% 3$ azalma meydana gelmiştir. Uçucu küllü numunelerde ve hem silis dumanı hem de uçucu kül içeren numunelerde ise deniz suyu etkisinde 90 günlük basınç dayanımları 28 günlük basınç dayanımlarına göre sırasıyla $\% 16$ ve $\% 21$ artma göstermiştir. Basınç dayanımının bu kadar artması uçucu küllü ve silis dumanlı numunelerin deniz suyundan fazla etkilenmediğini, devam eden hidratasyon reaksiyonları sebebiyle deniz suyu ortamında betonların 90. günde (28. güne göre) basınç dayanımında artışlar meydana gelmiştir.

İki ay sülfürik asit etkisine maruz kalan betonlarda ise 90 günlük basınç dayanımlarında (28.güne göre) ciddi azalmalar meydana gelmiştir. Kontrol betonu ve cüruf betonunun 90. gün basınç dayanımları 28. gün basınç dayanımlarına göre sırasıyla $\% 40$ ve $\% 41$ azalmıştır. Uçucu küllü betonda ise bu azalma \%34 iken, silis dumanı ve uçucu küllü betonda ise \%17 azalma meydana gelmiştir. Betonlarda sülfürik asit etkisiyle fazla bozulmalarını sebebi olarak betonlardaki yüksek $\mathrm{CaO}$ miktarı gösterilebilir. Yüksek $\mathrm{CaO}$ miktarına sahip betonlar daha fazla alçıtaşı oluşumuna sebep olacağı için fazla miktarda bozulma gösterecektir. En yüksek $\mathrm{CaO}$ miktarı kontrol ve cüruflu betonlarda olduğu için asit nedeniyle bozulma en fazla kontrol ve cüruflu betonlarda görülmüştür. Uçucu küllü betonda daha az bozulma görülürken, hem silis dumanı hem de uçucu kül içeren betondaki bozulmanın daha az olması düşük $\mathrm{CaO}$ miktarına ve de silis dumanı sayesinde geçirimliliğin azalmasından kaynaklanmaktadır. Sonuçlara göre $500 \mathrm{~kg}$ bağlayıcı ve eşdeğer su/çimento oranı 0,53 olan cüruf betonu ile $400 \mathrm{~kg}$ bağlayıcı (çimento) içeren ve eşdeğer su/çimento oranı 0,45 olan kontrol betonu asit ortamından en fazla zarar gören betonlardır. Normalde en fazla bozulmanın daha yüksek su/çimento oranına sahip betonlarda olması beklenirken daha düşük su/çimento oranı olan kontrol betonu, cüruflu betonla aynı miktarda bozulma (\%40) göstermiştir. Bu iki betondan sonra $0,45 \mathrm{su} /$ çimento oranına sahip ve $470 \mathrm{~kg}$ bağlayıcı içeren uçucu küllü betonda asit ortamından dolayı basınç dayanımında azalma (\%34) gerçekleşmiştir. En az bozulma (\%17) ise 0,53 eşdeğer su/çimento oranına sahip ve $440 \mathrm{~kg}$ bağlayıcı içeren uçucu küllü ve silis dumanlı betonda gerçekleşmiştir. Silis dumanının betondaki boşlukları doldurarak geçirimliliği azalttığı ve beton performansını iyileştirdiği görülmektedir.

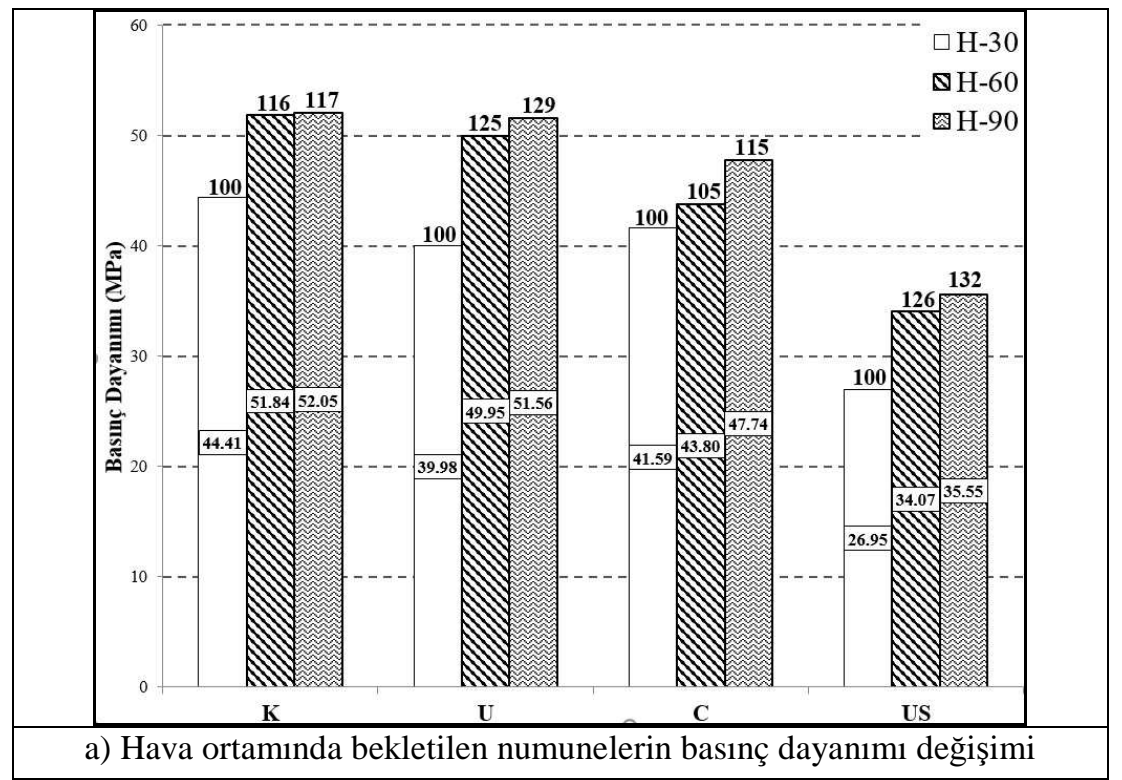

Şekil 4. Farklı kimyasal ortamlar etkisindeki numunelerin basınç dayanımı değişimi. 
Niș A.

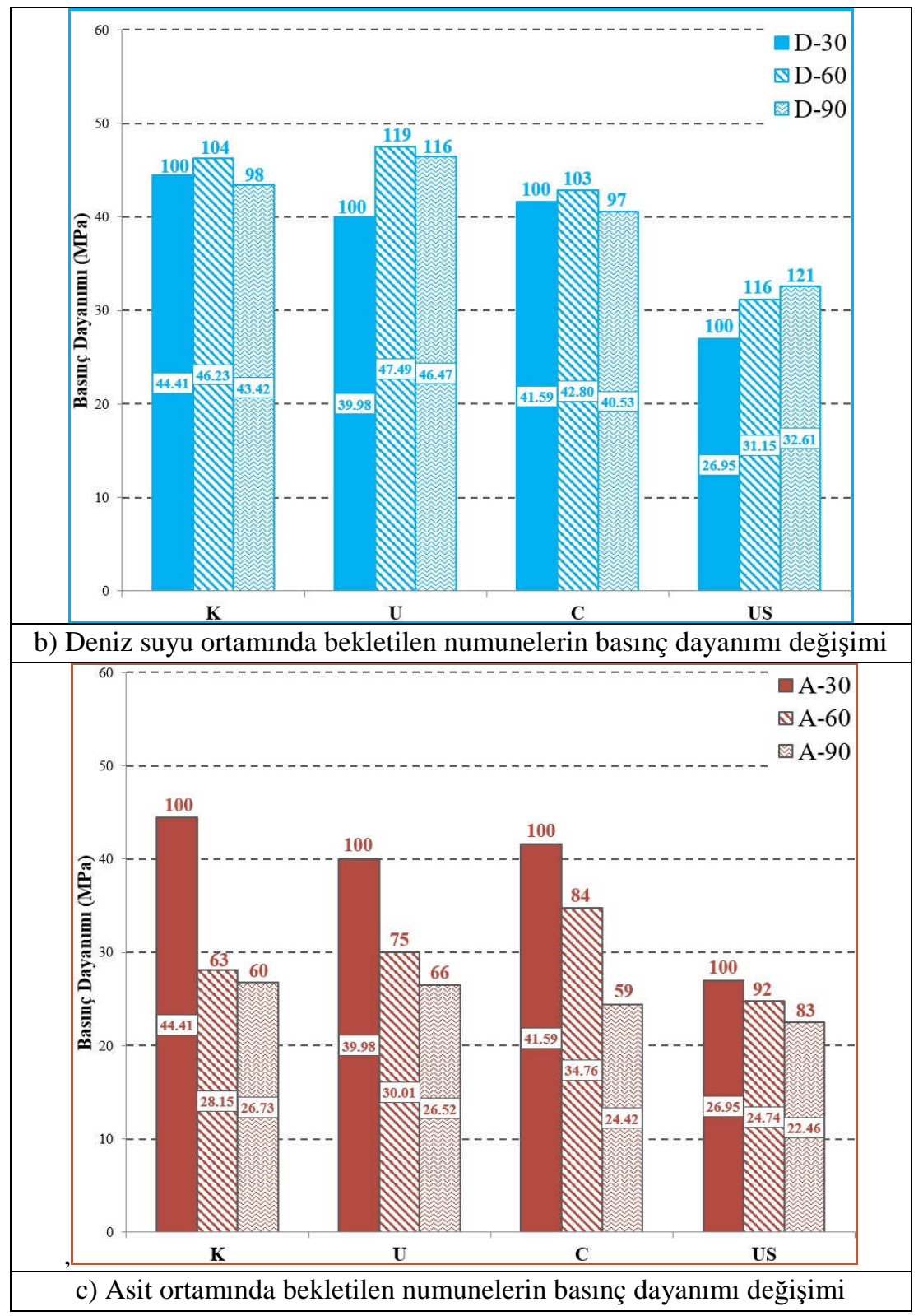

Şekil 4. (Devami).

\section{Sonuçlar}

$\mathrm{Bu}$ çalışmada farklı mineral katkı içeren betonların kimyasal ortamlardaki durabilite performansı toplam bağlayıcı miktarı ve eş değer su/çimento oranı parametreleriyle incelenmiş ve aşağıdaki sonuçlar elde edilmiştir:

- Bağlayıcı miktarı ile karşılaştırma yapıldığında; kimyasal etki sebebiyle en fazla dayanım kaybı $500 \mathrm{~kg}$ bağlayıcı içeren cüruflu ve $400 \mathrm{~kg}$ çimento içeren kontrol betonlarında, daha sonra $470 \mathrm{~kg}$ bağlayıcı içeren uçucu küllü betonda ve en az dayanım kaybı ise $440 \mathrm{~kg}$ silis dumanlı ve uçucu küllü betonda görülmüsstür. 
- Eşdeğer su/çimento oranı ile karşılaştırılma yapıldığında betonda en fazla dayanım kaybı 0,53 ve 0,45 eşdeğer su/çimento oranlarına sahip cüruflu ve kontrol betonlarında, daha az dayanım kaybı 0,45 eşdeğer su/çimento oranına sahip uçucu küllü betonda ve en az dayanım kaybı ise 0,53 eşdeğer su/çimento oranına sahip olan silis dumanlı ve uçucu küllü betonda gerçekleşmiştir.

- Betonların 90. gündeki basınç dayanımı değerleri karşılaştırıldığında, cüruflu beton ( 48 MPa) ile kontrol betonu ( 52 MPa) arasındaki dayanım farkı hava ortamında yaklaşık $4 \mathrm{MPa}$ iken, bu oran deniz suyu ortamında yaklaşık $3 \mathrm{MPa}$ ( 43 MPa, 46 MPa), asit ortamında ise dayanım farkı yaklaşık $2 \mathrm{MPa}$ 'dır ( 26 $\mathrm{MPa}, 24 \mathrm{MPa})$. Her iki betonun kimyasal etkilere karşı performansı karşılaştırıldığında cüruflu betonun performansı kontrol betonunun en az 0,45 eşdeğer su/çimento oranı dayanım ve kimyasal durabilite performansına sahip olduğu sonucuna varılmıştır. Bu yüzden cüruflu betonda eşdeğer su /çimento oranı hesaplanırken hesaplara katılması gereken cüruf miktarı çimento miktarının \%45'i yerine \%55-\%60 arası değer alınmalıdır. Mineral katkılı betonlar arasında kimyasal etkilere karşı en kötü performansı cüruflu beton göstermiştir.

- Uçucu küllü beton performansı değerlendirildiğinde eşdeğer su/çimento hesapları hem dayanım açısından hem de durabilite açısından uygundur. Uçucu küllü betonunun kimyasal etkilere karşı durabilitesinin kontrol betonundan daha iyi olması düşük $\mathrm{CaO}$ miktarına sahip olmasından kaynaklanmaktadır.

- Silis dumanı içeren betonların basınç dayanımının beklenilenden daha düşük çıkması hem düşük $\mathrm{CaO}$ miktarına hem de silis dumanının en fazla \%4 ile \%5 miktarlarının bağlayıcı olarak görev alması ve fazla silis dumanının boşlukları doldurmada (geçirimliliğin azalması) görev almasından kaynaklanabilir. Silis dumanının \%11'lere kadar eşdeğer su/çimento hesaplarında kullanımı özellikle uçucu kül içeren betonlarda daha fazla çalışma ile araştırılması gerekmektedir.

\section{Teşekkür}

Malzeme katkılarından dolayı AKÇANSA firmasına teşekkür ederiz.

\section{Kaynaklar}

[1] Andrew, R.M., Global CO2 emissions from cement production, Earth System Science Data, 10(1), 195-217, (2018).

[2] Duan, P., Shui, Z., Chen, W., ve Shen, C., Effects of metakaolin, silica fume and slag on pore structure, interfacial transition zone and compressive strength of concrete, Construction and Building Materials, 44, 1-6, (2013).

[3] Aydın, S., Yazıcı, H., Yiğiter, H., ve Baradan, B., Sulfuric acid resistance of high-volume fly ash concrete, Building and Environment, 42(2), 717-721, (2007).

[4] Oner, A., Akyuz, S., ve Yildiz, R. An experimental study on strength development of concrete containing fly ash and optimum usage of fly ash in concrete, Cement and Concrete Research, 35(6), 1165-1171, (2005). 
[5] ACI Committee 211, Guide for selecting proportions for high-strength concrete with Portland cement and fly ash, ACI Materials Journal, (1993).

[6] Saha, A.K., Effect of class F fly ash on the durability properties of concrete, Sustainable Environment Research, 28(1), 25-31, (2018).

[7] Imbabi, M.S., Carrigan, C., ve McKenna, S., Trends and developments in green cement and concrete technology, International Journal of Sustainable Built Environment, 1(2), 194-216, (2012).

[8] Chindaprasirt, P., Chotithanorm, C., Cao, H.T., ve Sirivivatnanon, V., Influence of fly ash fineness on the chloride penetration of concrete, Construction and Building Materials, 21(2), 356-361, (2007).

[9] Tokyay, M., Betonda UK, GYFC ve SD'nin Rolü: Mevcut Bilgi Birikimi, Beton 2013 Hazır Beton Kongresi, 21-23 Şubat, 201-238, (2013).

[10] Tavasoli, S., Nili, M., ve Serpoosh, B., Effect of GGBS on the frost resistance of self-consolidating concrete, Construction and Building Materials, 165, 717722, (2018).

[11] Aldea, C.M., Young, F., Wang, K., ve Shah, S.P., Effects of curing conditions on properties of concrete using slag replacement, Cement and Concrete Research, 30(3), 465-472, (2000).

[12] Abdelkader, B., El-Hadj, K., ve Karim, E., Efficiency of granulated blast furnace slag replacement of cement according to the equivalent binder concept, Cement and Concrete Composites, 32, 3, 226-231, (2010).

[13] Dotto, J.M.R., De Abreu, A.G., Dal Molin, D.C.C., ve Müller, I.L., Influence of silica fume addition on concretes physical properties and on corrosion behaviour of reinforcement bars, Cement and Concrete Composites, 26(1), 31-39, (2004).

[14] Panjehpour, M., Ali, A.A.A., ve Demirboga, R., A review for characterization of silica fume and its effects on concrete properties, International Journal of Sustainable Construction Engineering and Technology, 2(2), (2011).

[15] Chung, D.D.L, Improving cement-based materials by using silica fume, Journal of Materials Science, 37(4), 673-682, (2002).

[16] Pala, M., Özbay, E., Öztaş, A., ve Yuce, M. I., Appraisal of long-term effects of fly ash and silica fume on compressive strength of concrete by neural networks, Construction and Building Materials, 21(2), 384-394, (2007).

[17] Pedro, D., De Brito, J., ve Evangelista, L., Evaluation of high-performance concrete with recycled aggregates: Use of densified silica fume as cement replacement, Construction and Building Materials, 147, 803-814, (2017)

[18] Yajun, J., ve Cahyadi, J.H., Effects of densified silica fume on microstructure and compressive strength of blended cement pastes, Cement and Concrete Research, 33(10), 1543-1548, (2003).

[19] Zhang, Z., Zhang, B., ve Yan, P., Comparative study of effect of raw and densified silica fume in the paste, mortar and concrete, Construction and Building Materials, 105, 82-93, (2016).

[20] Bhattacharya, M., ve Harish, K.V., An integrated approach for studying the hydration of portland cement systems containing silica füme, Construction and Building Materials, 188, 1179-1192, (2018).

[21] Muralidharan, S., Parande, A.K., Saraswathy, V., Kumar, K., ve Palaniswamy, N., Effect of silica fume on the corrosion performance of reinforcements in concrete, Zaštita materijala, 49(4), 3-8, (2008). 
[22] Song, H.W., Pack, S.W., Nam, S.H., Jang, J.C., ve Saraswathy, V., Estimation of the permeability of silica fume cement concrete, Construction and Building Materials, 24(3), 315-321, (2010).

[23] TS 13515, Complementary standard for application of TS EN 206-1, Türk Standartları, Ankara, (2012).

[24] ASTM C39/C39M-01, American Society for Testing and Materials. Standard test method for compressive strength of cylindrical concrete specimens, American Standard, Philadelphia, (2001).

[25] Bakharev, T., Resistance of geopolymer materials to acid attack, Cement and Concrete Research, 35(4), 658-670, (2005)

[26] Çevik, A., Alzeebaree, R., Humur, G., Niş, A., ve Gülşan, M.E., Effect of nanosilica on the chemical durability and mechanical performance of fly ash based geopolymer concrete, Ceramics International, 44(11), 12253-12264, (2018).

[27] Bassuoni, M.T., ve Nehdi, M.L., Resistance of self-consolidating concrete to sulfuric acid attack with consecutive $\mathrm{pH}$ reduction, Cement and Concrete Research, 37(7), 1070-1084, (2007).

[28] Wallah, S., ve Rangan, B. V., Low-calcium fly ash-based geopolymer concrete: long-term properties, (2006).

[29] Gülşan, M.E., Mohammedameen, A., Şahmaran, M., Niş, A., Alzeebaree, R., ve Abdulkadir, Ç., Effects of sulphuric acid on mechanical and durability properties of ECC confined by FRP fabrics, Advances in Concrete Construction, 6(2), 199-220, (2018).

[30] S. Li ve D. M. Roy, Preparation and characterization of high and low $\mathrm{CaO} / \mathrm{SiO} 2$ ratio 'pure' C--S--H for chemically bonded ceramics, Journal of Material Research, 3(2), 380-386, (1988).

[31] Li, Z. ve Ding, Z., Property improvement of Portland cement by incorporating with metakaolin and slag, Cement and Concrete Research, 33(4), 579-584, (2003).

[32] Zhutovsky, S., ve Hooton, R.D., Accelerated testing of cementitious materials for resistance to physical sulfate attack, Construction and Building Materials, 145, 98-106, (2017).

[33] Al-Dulaijan, S.U., Macphee, D.E., Maslehuddin, M., Al-Zahrani, M.M. ve Ali, M.R., Performance of plain and blended cements exposed to high sulphate concentrations, Advances in Cement Research,19, 4, 9, (2007).

[34] Thokchom, S., Fly ash geopolymer pastes in sulphuric acid, International Journal of Engineering Innivation and Research, 3(6), 943-947, (2014).

[35] Attiogbe, E.K. ve Rizkalla, S.H., Response of concrete to sulfuric acid attack, ACI Material Journal, 85, 481-488, (1988).

[36] Sanni, S. H., ve Khadiranaikar, R. B., Performance of geopolymer concrete under severe environmental conditions, International Journal of Civil and Structural Engineering, 3, 2, 396, (2012).

[37] Santhanam, M., Cohen, M. D., ve Olek, J., Sulfate attack research-whither now?, Cement and Concrete Research, 31(6), 845-851, (2001). 